\title{
Horizontes de nuestra revista
}

\section{Horizons of our journal}

Nuestra revista ha cumplido por más de cincuenta años con su labor primordial establecida por los fundadores, ser el medio de difusión del trabajo y de la investigación de los cirujanos chilenos.

En los últimos años hemos asistido a la internacionalización de nuestra publicación, ello ha sido producto de haber logrado su indización en importantes bibliotecas científicas, tal como SciELO, además de su ingreso a Science Citation Index Expanded de Thompson Reuters (ISI).

Dicha difusión global ha significado además, que estamos publicando parte de la producción académica y científica de varios países de la región americana, así como también de Europa y Asia.

Recientemente, el grupo de investigación de Temuco ha dado a conocer en nuestra revista el resultado de sus estudios de análisis biliométrico referentes al impacto y visibilidad que ha significado nuestra indización internacional. Los resultados son muy gratos y alentadores.

Ahora viene otra etapa. Luego de varias reuniones con el Directorio y de una encuesta realizada a nuestros socios a nivel nacional, se ha decidido trasformar la revista al formato electrónico, ello se hará en tres etapas pues muchos de los médicos encuestados prefieren continuar recibiendo el formato en papel. En la primera etapa, se está trabajando en una página web lo más moderna posible, con grados de interactividad editorial. En la segunda etapa, una vez que el formato electrónico esté operativo, se imprimirá en papel sólo la mitad de lo que se realiza actualmente. En la tercera etapa, en un plazo aun no definido, la revista será sólo electrónica.

No cabe duda que el acceso a este último medio es más inmediato, fácil y global. Con el desarrollo actual tecnológico, los interesados pueden revisar las publicaciones en cualquier lugar, sólo desde su teléfono o cualquier otro medio apropiado.

Durante el trascurso del año intentaremos dar otros pasos tendientes al aumento de nuestra visibilidad internacional.

Lo importante es seguir avanzando, creo que estamos en la senda.

Dr. Julio Yarmuch G. Editor Jefe 